\title{
Posttraumatic Growth in
} Postlingually Deaf Patients With Cochlear Implants: The Effect of Stress-Coping Strategies, Sociodemographics, and Deafness-Related Factors

\author{
Joanna Kobosko ${ }^{1,2}$, W. Wiktor Jedrzejczak ${ }^{1,2 *}$, D. Beata Porembska ${ }^{1,2,3}$, \\ Anna Geremek-Samsonowicz ${ }^{1,2}$ and Henryk Skarzynski ${ }^{1,2}$ \\ ${ }^{1}$ Institute of Physiology and Pathology of Hearing, Warsaw, Poland, ${ }^{2}$ World Hearing Center, Nadarzyn, Poland, ${ }^{3}$ The Maria \\ Grzegorzewska University, Warsaw, Poland
}

OPEN ACCESS

Edited by:

Gianluca Castelnuovo,

Catholic University of the Sacred

Heart, Italy

Reviewed by:

Robert S. C. Cowan,

The University of Melbourne, Australia

Sébastien Paquette,

McGill University, Canada

${ }^{*}$ Correspondence: W. Wiktor Jedrzejczak

w.wiktor.jgmail.com

Specialty section: This article was submitted to Psychology for Clinical Settings,

a section of the journal

Frontiers in Psychology

Received: 29 April 2020

Accepted: 19 July 2021

Published: 17 August 2021

Citation:

Kobosko J, Jedrzejczak WW, Porembska DB,

Geremek-Samsonowicz $A$ and

Skarzynski H (2021) Posttraumatic Growth in Postlingually Deaf Patients With Cochlear Implants: The Effect of

Stress-Coping Strategies,

Sociodemographics, and

Deafness-Related Factors.

Front. Psychol. 12:546896

doi: 10.3389/fpsyg.2021.546896
The aim of this study was to assess whether cochlear implant $(\mathrm{Cl})$ users who had been postlingually deaf developed a more positive outlook on life-the so-called posttraumatic growth (PTG) - as a result of their disability and to examine how PTG related to their stress-coping strategies and personal circumstances. The study group consisted of 119 postlingually deaf $\mathrm{Cl}$ users. The participants were asked to anonymously fill in several questionnaires: the Post-Traumatic Growth Inventory (PTGI), Coping Orientations to Problems Experienced (Brief COPE), and a form asking for personal details and factors related to their deafness and $\mathrm{Cl}$ use. The PTG of postlingually deaf $\mathrm{Cl}$ users was similar to that found in people with other severe health problems. The time that had elapsed since the hearing was lost and the time from receiving a $\mathrm{Cl}$ were positively correlated with PTG. The level of PTG was correlated with the particular coping strategies used and differed between men and women. We found that the development of PTG could emerge from both approach-oriented coping strategies (e.g., active coping and planning) and avoidance-oriented coping strategies (e.g., denial, self-distraction, and self-blame). Paradoxically, the avoidance strategies could play a positive role in the development of PTG. This reinforces the idea, previously raised in the PTG literature, that such strategies exert a defensive and protective function - an "illusory" side of PTG-which operates together with the positive constructive side, and both help develop the sense of well-being of a person.

Keywords: posttraumatic growth, postlingual deafness, stress coping strategies, gender differences, cochlear implant

\section{INTRODUCTION}

Postlingually acquired deafness or profound hearing loss is a highly stressful life event, which usually arrives as a severe shock in the life of a person (Hallberg and Carlsson, 1993; Kerr and Cowie, 1997; Heydebrand et al., 2005; Hallam et al., 2006; Hallberg et al., 2008; Kashubeck-West and Meyer, 2008; Du Feu, 2014; Kobosko, 2015; Williams et al., 2015). Whether someone loses 
hearing gradually or suddenly--for example, as a result of illness or accident--it is likely to be an adverse/traumatic experience (Du Feu and Fergusson, 2003). However, when we look at it from the perspective of positive psychology, people who lose their hearing have the chance to experience positive changes as a result of this impact on their life--a change that is referred to as posttraumatic growth (PTG). This theoretical concept suggested by Tedeschi and Calhoun (2004), Calhoun and Tedeschi (2014), and Martz and Livneh (2016) has been backed up by numerous studies on people with chronic illness or disabilities (CID) and by systematic reviews (Barskova and Oesterreich, 2009; Harding et al., 2014; Koutrouli et al., 2014; Ogińska-Bulik, 2015; Rzeszutek and Gruszczyńska, 2018; Wu et al., 2019). However, the phenomenon of PTG has not yet been studied in a population of postlingually deaf people, i.e., those who have experienced hearing loss following their acquisition of speech and language.

The difficulties experienced by someone who has postlingually lost hearing relate not only to day-to-day speech and limitations in verbal communication but also to longer-term difficulties in interpersonal relations with family, friends, and work colleagues. The problems can extend to various social situations, which can be highly negative, sometimes amounting to stigmatization (Kerr and Cowie, 1997; Kashubeck-West and Meyer, 2008; Du Feu, 2014; Williams et al., 2015). Such difficulties often produce high levels of psychological distress, depression, and anxiety (Hallam et al., 2006; Fellinger et al., 2012; Du Feu, 2014), and lead to lowered satisfaction with life and general loss of well-being (Kerr and Cowie, 1997; Heydebrand et al., 2005; Kashubeck-West and Meyer, 2008; Kobosko, 2015; Williams et al., 2015).

People who become postlingually deaf can benefit from a cochlear implant (CI) (Hallberg and Ringdahl, 2004; Heydebrand et al., 2005; Lassaleta et al., 2006; Kennedy et al., 2008; Rembar et al., 2009; Rostkowska et al., 2012; Ramos-Macías et al., 2016). This is a device that is surgically implanted into the head and transforms sound into electric stimuli that are in turn transmitted to the nervous system (Lazard et al., 2012; Blamey et al., 2013). It provides a new way of perceiving sounds, and most importantly speech. In Poland, CIs have been available since 1992 (Skarżyński et al., 1993), and many studies have shown that they improve health-related quality of life.

As we know from our clinical practice, when deafness first occurs it is perceived by the patient as "something terrible," "a collapse of the world," "a black abyss," or a "situation without exit." However, in light of the positive psychology just mentioned, they may also experience PTG--positive changes in various areas of their life (although not all patients do so). When a patient with postlingual profound hearing loss is first provided with a $\mathrm{CI}$, the device and the ability to hear again help them adapt to their deafness. Hence, cochlear implantation is perceived by most CI users as a positive (not an adverse) experience-as can be indirectly concluded from the reports of postlingually deaf CI users and their significant others (Hallberg and Ringdahl, 2004; Heydebrand et al., 2005; Kennedy et al., 2008). Our own years of experience of working with such patients confirms that view. However, the complication is that a CI cannot, by itself, be treated as a source of PTG. In fact, a CI may indirectly promote PTG as the by-product of a particular stress-coping strategy.
To date, only a few researchers have looked at the positive aspects of hearing loss. For example, Kerr and Cowie (1997) and Stephens and Kerr (2003) found that the experience of acquired deafness can enrich life by contributing to, among other things, "developing a better understanding of human nature." Some people with hearing loss have done so with great success (Manchaiah et al., 2015), but it is not known whether, when finding positive aspects to their hearing loss, they also experienced PTG, because not every positive change indicates the development of PTG.

To the best of our knowledge, there has been no research on the PTG that may occur in the personal development of postlingually deaf people who have also become CI users.

\section{Posttraumatic Growth and Chronic IIIness or Disability}

In order to understand how trauma might lead to possible positive outcomes, Tedeschi and Calhoun (2004) and Calhoun and Tedeschi (2014) introduced the concept of PTG. Their concept posits that an encounter with trauma can become the source of a highly positive change in a person. The way the PTG concept is used here is that the trauma of a subject is synonymous with a "crisis (or) major stressor (which) describe circumstances that significantly challenge or invalidate important components of the individual's assumptive world" (Tedeschi and Calhoun, 2004; Calhoun and Tedeschi, 2014). It is a "seismic event." The authors of the PTG concept emphasized that PTG is an inevitable concomitant of how trauma is coped with, not a secondary mechanism that an individual calls on in order to cope. Importantly, PTG involves the appearance of positive changes which go beyond the level of psychological functioning of a person which existed prior to the trauma (Calhoun and Tedeschi, 2014). Of course, PTG can also be accompanied by psychological distress (Tedeschi and Calhoun, 2004; Calhoun and Tedeschi, 2014).

Research on PTG in the domain of health has mainly been carried out on patients with chronic, serious, and sometimes incurable diseases such as cancer (Cordova et al., 2001; Steel et al., 2008; Barskova and Oesterreich, 2009; Jansen et al., 2011; Scrignaro et al., 2011; Harding et al., 2014; Koutrouli et al., 2014; Andysz et al., 2015; Mazurkiewicz et al., 2015; Ogińska-Bulik, 2015), heart problems (Barskova and Oesterreich, 2009; Łosiak and Nikiel, 2014; Ogińska-Bulik, 2015; Juczyński and Ogrodnik, 2017), and AIDS/HIV (Barskova and Oesterreich, 2009; Calhoun and Tedeschi, 2014; Ogińska-Bulik, 2015; Rzeszutek et al., 2016; Rzeszutek and Gruszczyńska, 2018). Less often, PTG has been applied to people with permanent health losses such as those with spinal cord injuries (Ogińska-Bulik, 2015; Byra, 2016). Research has uncovered strong associations between PTG and health levels, treatment and recovery paths, and attitudes to life (Cordova et al., 2001; Barskova and Oesterreich, 2009; Bostock et al., 2009; Calhoun and Tedeschi, 2014; Andysz et al., 2015; Ogińska-Bulik, 2015; Rzeszutek et al., 2016; Juczyński and Ogrodnik, 2017). PTG may be affected by gender (but not always) (Tedeschi and Calhoun, 1996, 2004; Barskova and Oesterreich, 2009; Vishnevsky et al., 2010; Ogińska-Bulik, 2013; 
Akbar and Witruk, 2016; Baghjari et al., 2017), age (Barskova and Oesterreich, 2009; Prati and Pietrantoni, 2009; Ogińska-Bulik, 2013, 2015; Calhoun and Tedeschi, 2014), and time since the traumatic event (Cordova et al., 2001; Barskova and Oesterreich, 2009; Ogińska-Bulik, 2015; Kobosko, 2016; Rzeszutek et al., 2016).

\section{Posttraumatic Growth and Coping With Stress}

Research interest in PTG has also focused on understanding how it relates to the coping strategies employed. Do each of the strategies support-or not support-the growth of PTG in people who have had various health-related traumatic events? In answering this question, studies have highlighted the importance of certain coping processes and strategies (Barskova and Oesterreich, 2009; Prati and Pietrantoni, 2009; OgińskaBulik, 2015). The cause of PTG appears not to be the trauma itself, but the way in which affected people cope with it (Barskova and Oesterreich, 2009; Calhoun and Tedeschi, 2014; Ogińska-Bulik, 2015). The literature already distinguished the approach-oriented coping strategies, which are aimed at taking action to reduce the level of stress, and the avoidance-oriented coping strategies, which act by distancing the person from the source of stress (Roth and Cohen, 1986; Carver, 1997).

The approach-oriented coping category includes strategies that are considered effective in coping with stress and its effects, namely, active coping, planning, acceptance, and positive reframing (Barskova and Oesterreich, 2009; Prati and Pietrantoni, 2009; Ogińska-Bulik, 2015; Byra, 2016, Pérez-SanGregorio et al., 2017; Rzeszutek et al., 2017). Various studies have seen the development of PTG in people with cancer (Barskova and Oesterreich, 2009; Harding et al., 2014; Ogińska-Bulik, 2015; Baghjari et al., 2017; Boals et al., 2019), liver transplants (Pérez-San-Gregorio et al., 2017), and survivors of stroke (Kelly et al., 2018), all through using problem-focused coping and active coping.

At the same time, an increasing number of scientific papers also identify a role for avoidance-oriented coping strategies in the development of PTG, including coping through denial (Barskova and Oesterreich, 2009; Akbar and Witruk, 2016; Pérez-SanGregorio et al., 2017; Rzeszutek et al., 2017; Kunz et al., 2018). Paradoxically, perhaps, these strategies appear to have what seem like positive outcomes. The recently published longitudinal study by Kunz et al. (2018) shows that the flexible use of both approach- and avoidance-oriented coping strategies contributes to PTG. However, we believed that denial coping may in fact favor the development, not of constructive PTG, but what has been called "illusory" PTG by the creators of the Janus-face model of PTG (Zoellner and Maercker, 2006). Due to self-reporting, the difficulty is to distinguish between the two, but some researchers claimed to have found actual and illusory PTG (Boals et al., 2019).

Coping strategies beyond the typical approach-oriented and avoidance-oriented coping strategies for stress also play an important role in the development of PTG, notably religious coping (Barskova and Oesterreich, 2009; Prati and Pietrantoni, 2009; Ogińska-Bulik, 2014, 2015; Byra, 2016; García et al., 2017;
Kelly et al., 2018) and humor (Barskova and Oesterreich, 2009; Rajandram et al., 2011; Ogińska-Bulik, 2014, 2015; Byra, 2016). Certainly, the role of social support (in the form of seeking instrumental and emotional support) in the development of PTG in people affected by trauma is also an invaluable coping strategy, especially in patients with CID (Cordova et al., 2001; Barskova and Oesterreich, 2009; Prati and Pietrantoni, 2009; Rajandram et al., 2011; Scrignaro et al., 2011; Calhoun and Tedeschi, 2014; Ogińska-Bulik, 2015; Byra, 2016; Baghjari et al., 2017; García et al., 2017; Juczyński and Ogrodnik, 2017; Pérez-San-Gregorio et al., 2017; Kelly et al., 2018).

\section{Posttraumatic Growth, Coping, and Postlingual Deafness}

The traumatic event in the spotlight of this work is profound or total loss of hearing. Most postlingually deaf CI users, when confronted with stress as a result of deafness, generally resort to approach-oriented coping strategies, but younger users are more likely to use active coping (Kobosko et al., 2015). Our previous studies have shown that CI users are also likely to resort to avoidance-oriented coping strategies such as self-distraction, denial, venting, and behavioral disengagement; some may use religious coping (Kobosko et al., 2012, 2015). Over the several years of using a CI, the same strategy (e.g., venting) may perform different psychological functions: in patients with a short CI experience venting is negatively correlated with CI satisfaction, but in those with longer CI experience venting correlates positively with CI satisfaction (Kobosko et al., 2015). There are also sex differences; although both postlingually deaf men and women with a CI do not differ overall in coping strategies, women with a CI are more likely to use maladaptive coping strategies as compared with women in the general population (Kobosko et al., 2012).

\section{This Study}

The rationale for this study rests on noting that acquired deafness (and CI implantation as the avenue for treating it) involves not only rehabilitating hearing, speech, and communication, but also engaging dynamic psychological processes. These processes may be social relationships, identity reformulation, recognition of a new reality (either external or internal) related to the acquired disability of an individual, and a search for ways to cope with the situation of no longer being a hearing person. But, to date, there has been no research on the incidence of PTG as a result of acquired deafness and its psychological correlates, prompting us to investigate this phenomenon. We also wanted to look at the relationship between PTG and coping strategies in people with postlingual deafness.

The purpose of this study was to examine postlingually deaf CI users and see whether the PTG phenomenon occurred and, if so, at what level (low, medium, or high). In a similar manner, we wanted to investigate the links between the stress-coping strategies such people use and the level of PTG they attained. Relevant here are the sociodemographic characteristics of the postlingually deaf CI users (i.e., age, gender, education, marital or partnership status, and employment status) and the factors directly linked to deafness (i.e., the years of having serious 
TABLE 1 | Personal characteristics of subjects, Cl data, and hearing status of all participants.

\begin{tabular}{|c|c|c|c|c|c|}
\hline & & All participants & Men & Women & $\begin{array}{c}\text { Statistical test between } \\
\text { men/women }\end{array}$ \\
\hline$N$ & & 119 & 50 & 69 & \\
\hline \multirow[t]{2}{*}{ Age, yr } & Mean (SD) & $57(12)$ & $59(12)$ & $57(13)$ & $t_{(117)}=0.651 ; N S$ \\
\hline & Range & $24-80$ & $27-79$ & $24-80$ & \\
\hline$N$ (younger <60 yr) & & 60 & 24 & 36 & $\chi^{2}(1)=0.202 ; N S$ \\
\hline$N$ (older > 60 yr) & & 59 & 26 & 33 & \\
\hline \multirow[t]{2}{*}{ Educational status } & Primary or secondary (\%) & 62.2 & 64.0 & 60.9 & $\chi^{2}(1)=0.121 ; N S$ \\
\hline & Diploma or university (\%) & 37.8 & 36.0 & 39.1 & \\
\hline \multirow[t]{2}{*}{ Marital (partnership) status } & In a relationship (\%) & 32.8 & 24.0 & 39.1 & $\chi^{2}(1)=3.012 ; N S$ \\
\hline & Not in a relationship (\%) & 67.2 & 76.0 & 60.9 & \\
\hline \multirow[t]{2}{*}{ Employment (or study) } & Employed (or studying) (\%) & 45.4 & 48.0 & 43.5 & $\chi^{2}(1)=0.239 ; N S$ \\
\hline & Unemployed (\%) & 54.6 & 52.0 & 56.5 & \\
\hline \multirow[t]{2}{*}{ Duration of deafness (yr) } & Mean (SD) & $26(15)$ & $24(17)$ & $28(14)$ & $t_{(117)}=-1.14 ; N S$ \\
\hline & Range & $1-64$ & $1-64$ & $2-60$ & \\
\hline \multirow[t]{2}{*}{ Age at $\mathrm{Cl}$} & Mean (SD) & $51(13)$ & $52(14)$ & $51(13)$ & $t_{(117)}=0.204 ; N S$ \\
\hline & Range & $14-78$ & $14-78$ & $22-75$ & \\
\hline \multirow[t]{2}{*}{$\mathrm{Cl}$ experience } & Mean (SD) & $6(5)$ & $7(6)$ & $6(4)$ & $U=1,645.5 ; N S$ \\
\hline & Range & $0.5-24$ & $0.5-24$ & $0.5-21$ & \\
\hline \multirow[t]{2}{*}{ Cl satisfaction (\%) } & Mean (SD) & $81(24)$ & $80(25)$ & $82(22)$ & $U=1,707 ; N S$ \\
\hline & Range & $0-100$ & $0-100$ & $0-100$ & \\
\hline \multirow[t]{3}{*}{ Type of amplification } & $\mathrm{Cl}(\%)$ & 40.3 & 50.0 & 33.3 & $\chi^{2}(2)=4.062 ; N S$ \\
\hline & $\mathrm{Cl}+\mathrm{HA}(\%)$ & 42.0 & 32.0 & 49.3 & \\
\hline & $2 \mathrm{Cl}(\%)$ & 17.7 & 18.0 & 17.4 & \\
\hline
\end{tabular}

NS, not significant $(P>0.05)$.

hearing difficulties or being deaf) and the CI implantation itself (i.e., age at CI, duration of CI use, and satisfaction with their CI).

\section{MATERIALS AND METHODS}

To assess PTG in postlingually deaf adult CI users, the PTG inventory (PTGI) suggested by Tedeschi and Calhoun (1996) was used. This questionnaire is commonly used to study PTG in people suffering from chronic, severe, or life-threatening illnesses and disabilities. PTGI is relatively short and has good psychometric properties, both in the original version (Tedeschi and Calhoun, 1996) and in its Polish adaptation (Juczyński and Ogińska-Bulik, 2010). For similar reasons, Brief COPE (Carver, 1997) in its Polish adaptation (Juczyński and OgińskaBulik, 2009) was chosen to evaluate stress-coping strategies. Its widespread use makes it possible to compare results for both Poland and internationally.

\section{Study Participants and Procedure}

The study included adults with postlingual deafness, i.e., acquired after acquisition of speech and language. The group consisted of $n=119$ persons (69 women and 50 men) with profound hearing loss (pure tone audiometry showing loss of $>90 \mathrm{~dB} \mathrm{HL}$ at frequencies of $0.25-8 \mathrm{kHz}$ ) acquired after age 4 . Their ages ranged from 24 to 80 years. Among the 119 participants, 50 also used a hearing aid (HA) in their second ear, whereas 20 had a second CI. The period of first CI use ranged from 0.5 to 24 years, and the length of having serious hearing difficulties or being deaf ranged from 1 to 64 years. The respondents themselves reported the year of hearing loss, and when they had a problem with giving the precise year, then, in accordance with instructions, they gave an indicative number of years from when, in their own opinion, they had a serious hearing problem or deafness. All participants of this study communicated in spoken Polish. Table 1 lists information about the study group: their personal details (i.e., gender, age, education, marital/partnership status, and employment/study status); details of their deafness (i.e., time span of experiencing deafness); and details of their CI (i.e., years of use; age at receiving the CI, satisfaction with the CI, and amplification type). Intergroup comparisons $\left(\chi^{2}\right)$ of the variables in relation to gender were calculated, and there were no significant differences.

The subjects were recruited from CI patients of the Institute of Physiology and Pathology of Hearing. During a rehabilitation camp, they were given an envelope with a cover letter asking them to voluntarily and anonymously participate in a scientific research project. The envelope also contained questionnaires that could be returned in a sealed envelope to the camp supervisor. The response rate was around 50\%. This is slightly less than in other studies conducted in our center by the correspondence method (Kobosko et al., 2015). The lower rate may be because some people felt uncomfortable in handing the completed questionnaires to the camp supervisor. As the data were collected without identifying the patients, it was not possible 
to match the questionnaires with audiometric tests; however, other studies have shown (de Graaf and Bijl, 2002; Fellinger et al., 2012; Kobosko et al., 2015) that there is no correlation between audiological outcomes and psychological well-being. Therefore, in this study, the priority was to obtain the most honest responses from the patients, which can only be done anonymously.

Statistical analysis was performed using the IBM SPSS software program, version 25.0 (IBM Corp., Armonk, NY, USA) and its following tests: Pearson's $\chi^{2}$ (for assessing differences between sociodemographic data), Student's $t$-test (for assessing differences between descriptive statistics of the psychological questionnaires), Pearson's correlation coefficient (for correlating PTG to psychological variables and the personal data of patients), and linear multiple regression (for assessing which variables can be used as predictors of PTG). A 95\% confidence level $(P<0.05)$ was chosen as the criterion of significance. When conducting multiple comparisons, $P$-values were adjusted using the Benjamini-Hochberg procedure to control for false discovery rates (Benjamini and Hochberg, 1995).

All procedures were approved by the ethics committee of the Institute of Physiology and Pathology of Hearing, Warsaw (approval number IFPS: /KB/02/2014). No written consent was provided, as the study was based on anonymous questionnaires.

\section{Measures}

Post-traumatic Growth Inventory (PTGI). This instrument (Tedeschi and Calhoun, 1996; Juczyński and Ogińska-Bulik, 2010) was used to assess positive changes flowing from the experience of acquired deafness. PTGI consists of 21 items, each of which has possible answers ranging from "0" ( $I$ did not experience this change as a result of $m y$ crisis) to " 5 " (I experienced this change to a very great degree as a result of my crisis). Instructions made it clear that answers should relate to one event, i.e., the loss of hearing. Examples of items from PTGI include I can better appreciate each day, or I discovered that I'm stronger than I thought I was. In the Polish adaptation, factor analysis resulted in an inventory consisting of four dimensions (and not, as in the original, 5). Factor analysis measured positive changes in the following areas: changes in perception of oneself, changes in relationships with others, greater appreciation for life, and spiritual changes. The sum of all these items gave a global PTGI, which ranged from 0 to 105 points. The higher the score, the more positive are the changes resulting from the traumatic event. According to Juczyński and Ogińska-Bulik (2009), Cronbach's $\alpha$ for the Polish version of PTGI is 0.93, and for the four dimensions, it varies from 0.63 to 0.87 . In this study, Cronbach's $\alpha$ for PTGI was found to be 0.95 , and for the individual dimensions it was 0.70-0.92.

Brief Coping Orientation to Problems Experienced (Brief COPE). This self-reporting questionnaire (Carver, 1997; Juczyński and Ogińska-Bulik, 2009) contains 28 items that assess coping strategies. It uses a 4-point scale from "0" (I never do this) to " 3 " (I almost always do this). Brief COPE measures 14 separate strategies for coping with stress based on a 2-item subscale. The strategies are as follows: active coping (undertaking actions aimed at improving the situation); planning (thinking and planning what to do); positive reframing (perceiving the situation in a better light); acceptance (accepting the situation and learning how to live with it); humor (joking and treating the situation as a game); turning to religion (praying and meditating to find consolation); using emotional support (seeking reassurance, understanding, and the support of other people); using instrumental support (seeking advice and aid from other people), self-distraction (taking up other activities to avoid thinking about the event); denial (denying the existence of the situation); venting (displaying negative emotions); substance use (resorting to psychoactive substances, e.g., alcohol, to alleviate unpleasant emotions); behavioral disengagement (hopelessness, giving up attempts to attain the goals of an individual); and self-blame (criticizing and blaming oneself for what happened). Each strategy is evaluated on the basis of the average of the two items. Reliability of Brief COPE was calculated using a split-half measure and the Guttman coefficient was 0.81 .

The inquiry form included questions about personal characteristics (i.e., gender, age, education, marital or partner status, employment, or study status), as well as variables related to deafness, e.g., when the loss of hearing happened, and questions related to the CI, e.g., how long have you been using the CI. There was one question to measure the satisfaction of subjects with their CI. The subject marked on a line the degree to which they were pleased with their CI: the line had no visible markings except it had a 0 at one end (dissatisfied) and a 10 at the other (very satisfied). The line, 161-mm long, was placed on a single page; the response was measured in millimeters and converted to a percentage. More about the method used for measuring CI satisfaction can be found elsewhere (Kobosko et al., 2015).

\section{RESULTS}

\section{Descriptive Statistics}

First the global levels of PTG for each subject were evaluated and referenced to the Polish sten standards derived from people who have had various other sorts of traumatic events. A score for global PTG of 0-53 points was rated as low PTG (stens 1-4), a score of 54-72 was rated as average PTG (stens 5 and 6), and a score of 73-105 (stens 7-10) was rated as high PTG (Juczyński and Ogińska-Bulik, 2010). The postlingually deaf CI users in this study had a global level of PTG of about average as compared with Polish standards; $31 \%$ had high global PTG values and 32\% had average global PTG.

Table 2 shows the results of PTGI (for four dimensions, and globally) for all participants, as well as divided by gender. No significant differences were observed between men and women.

Table 3 shows results of the Brief COPE inventory, again for all participants and divided by gender. Men and women differed in turning to religion, using emotional support, using instrumental support, self-distraction, denial, and venting. In these strategies, women had higher scores and the effect sizes were medium to large (0.5-1.0).

\section{Correlations}

Table 4 shows Pearson's correlations (for four dimensions and for global values) for the deafness experience of participants, duration of CI experience, and strategies for 
TABLE 2 | Posttraumatic Growth Inventory (PTGl) values for all participants, divided by gender.

\begin{tabular}{|c|c|c|c|c|}
\hline \multirow[t]{2}{*}{ Psychological variables } & \multirow{2}{*}{$\frac{\text { Mean (SD) }}{\text { All participants }}$} & \multirow{2}{*}{$\frac{\text { Mean (SD) }}{\text { Men }}$} & \multirow{2}{*}{$\frac{\text { Mean (SD) }}{\text { Women }}$} & \multirow{2}{*}{$\begin{array}{l}\text { Comparison between } \\
\text { men and women }\end{array}$} \\
\hline & & & & \\
\hline Changes in perception of oneself & $25.85(10.48)$ & $25.38(10.74)$ & $26.18(10.36)$ & $\begin{array}{c}t_{(117)}=-0.382 ; P=0.70 ; \\
d=0.07\end{array}$ \\
\hline Greater appreciation for life & $9.46(3.83)$ & $8.73(3.98)$ & $10.00(3.66)$ & $\begin{array}{c}t_{(117)}=-1.772 ; P=0.20 \\
d=0.33\end{array}$ \\
\hline Spiritual changes & $4.83(3.27)$ & $4.10(3.34)$ & $5.41(3.12)$ & $\begin{array}{c}t_{(117)}=-2.100 ; P=0.19 ; \\
d=0.40\end{array}$ \\
\hline
\end{tabular}

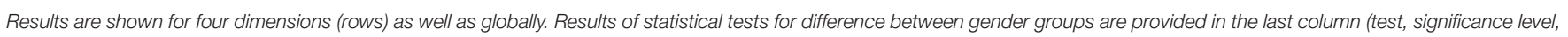
Cohen's d). There were no statistically significant differences between men and women.

TABLE 3 | Results of Brief COPE questionnaire for all participants, divided by gender.

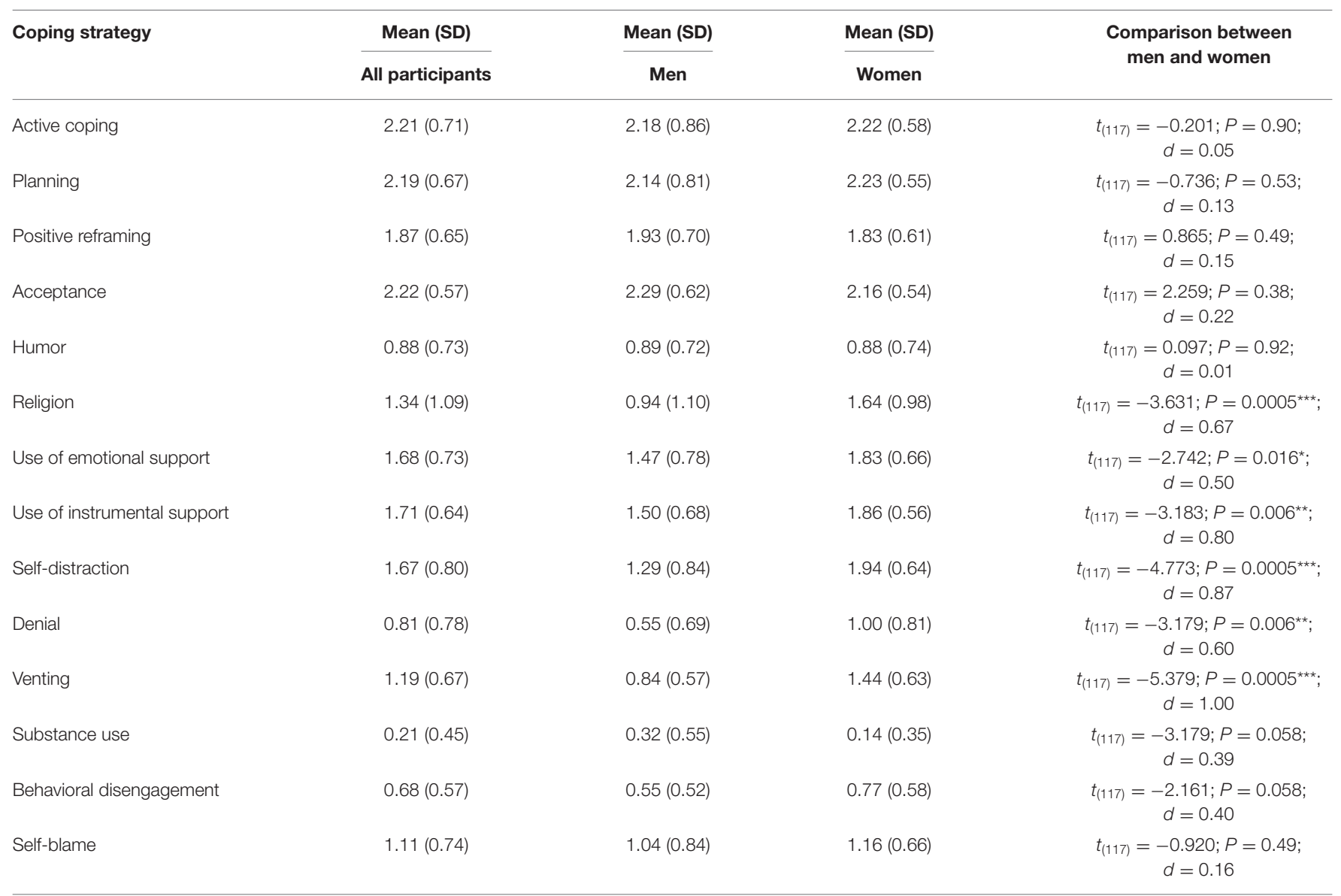

Results of statistical tests for differences between gender groups are listed in the last column (test, significance level, Cohen's d). ${ }^{*} P<0.05 ;{ }^{\star *} P<0.01 ;{ }^{* \star *} P<0.001$.

coping with stress (from Brief COPE). Age, age at CI, and CI satisfaction were not correlated with PTG. Duration of deafness correlated with changes in perception of oneself, changes in relationships with others, and global PTG (for men and for the whole group). CI experience correlated with changes in perception of oneself, greater appreciation for life (for women and for the whole group), and with global PTG for the whole group. 


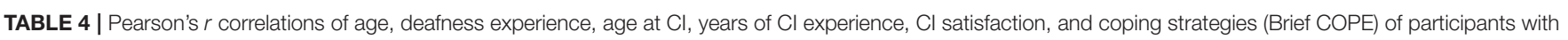
posttraumatic growth (for four dimensions and for global PTGl) among all participants, and divided by gender.

\begin{tabular}{|c|c|c|c|c|c|c|}
\hline & Group & $\begin{array}{c}\text { Global } \\
\text { posttraumatic } \\
\text { growth }\end{array}$ & $\begin{array}{c}\text { Changes in } \\
\text { perception of } \\
\text { oneself }\end{array}$ & $\begin{array}{l}\text { Changes in } \\
\text { relationships } \\
\text { with others }\end{array}$ & $\begin{array}{l}\text { Greater } \\
\text { appreciation } \\
\text { for life }\end{array}$ & $\begin{array}{l}\text { Spiritual } \\
\text { changes }\end{array}$ \\
\hline \multirow[t]{3}{*}{ Duration of deafness } & Men & $0.35^{\star}$ & $0.32^{\star}$ & $0.34^{\star}$ & NS & NS \\
\hline & Women & NS & NS & NS & NS & NS \\
\hline & All & $0.23^{\star}$ & $0.21^{\star}$ & $0.20^{\star}$ & NS & NS \\
\hline \multirow[t]{3}{*}{$\mathrm{Cl}$ experience } & Men & NS & NS & NS & NS & NS \\
\hline & Women & NS & $0.27^{\star}$ & NS & $0.27^{\star}$ & NS \\
\hline & All & $0.21^{*}$ & $0.26^{\star \star}$ & NS & $0.25^{\star \star}$ & NS \\
\hline \multirow[t]{3}{*}{ Active coping } & Men & NS & NS & NS & NS & NS \\
\hline & Women & $0.38^{\star \star}$ & $0.32^{\star}$ & NS & NS & NS \\
\hline & All & NS & NS & NS & NS & NS \\
\hline \multirow[t]{3}{*}{ Planning } & Men & NS & NS & NS & NS & NS \\
\hline & Women & $0.36^{\star \star}$ & $0.37^{\star \star}$ & NS & NS & NS \\
\hline & All & NS & NS & NS & NS & NS \\
\hline \multirow[t]{3}{*}{ Acceptance } & Men & NS & NS & NS & NS & NS \\
\hline & Women & NS & NS & $0.28^{\star}$ & NS & NS \\
\hline & All & NS & NS & NS & NS & NS \\
\hline \multirow[t]{3}{*}{ Religion } & Men & NS & NS & NS & NS & $0.58^{\star}$ \\
\hline & Women & NS & NS & NS & NS & $0.55^{\star \star \star}$ \\
\hline & All & $0.23^{\star}$ & NS & $0.22^{*}$ & NS & $0.59^{\star \star}$ \\
\hline \multirow[t]{3}{*}{ Use of emotional support } & Men & NS & NS & NS & NS & NS \\
\hline & Women & $0.28^{*}$ & NS & $0.28^{\star}$ & NS & NS \\
\hline & All & NS & NS & $0.29^{* *}$ & NS & NS \\
\hline \multirow[t]{3}{*}{ Use of instrumental support } & Men & NS & NS & $0.43^{\star \star}$ & NS & NS \\
\hline & Women & $0.34^{\star}$ & NS & $0.39 * \star$ & NS & $0.39^{\star *}$ \\
\hline & All & $0.33^{\star \star}$ & $0.19^{\star}$ & $0.41^{* *}$ & NS & $0.30^{\star *}$ \\
\hline \multirow[t]{3}{*}{ Self-distraction } & Men & NS & NS & NS & NS & NS \\
\hline & Women & $0.32^{*}$ & $0.35^{\star \star}$ & $0.25^{\star}$ & NS & NS \\
\hline & All & $0.24^{\star}$ & $0.25^{\star}$ & $0.20^{\star}$ & $0.26^{\star \star}$ & NS \\
\hline \multirow[t]{3}{*}{ Denial } & Men & NS & NS & NS & NS & NS \\
\hline & Women & $0.31^{*}$ & NS & $0.26^{\star}$ & NS & $0.31^{*}$ \\
\hline & All & $0.28^{\star \star}$ & NS & $0.19^{\star}$ & $0.18^{\star}$ & NS \\
\hline \multirow[t]{3}{*}{ Venting } & Men & NS & NS & NS & NS & NS \\
\hline & Women & $0.31^{*}$ & $0.30^{*}$ & NS & NS & NS \\
\hline & All & $0.27^{\star \star}$ & $0.21^{*}$ & $0.20^{\star}$ & $0.19^{\star}$ & $0.20^{\star}$ \\
\hline \multirow[t]{3}{*}{ Behavioral disengagement } & Men & NS & NS & NS & NS & NS \\
\hline & Women & NS & NS & NS & NS & NS \\
\hline & All & NS & NS & NS & NS & $0.26^{* \star}$ \\
\hline
\end{tabular}

Only variables for which there were significant correlations are shown.

NS, not significant.

${ }^{*} P<0.05 ;{ }^{* *} P<0.01 ;{ }^{* *} P<0.001$.

Significant correlations are shown in bold.

On the contrary, the Brief COPE correlated with PTG in several respects. In the case of the whole group, global PTG correlated significantly with religion, use of instrumental support, self-distraction, denial, and venting. In terms of all the dimensions of PTG, changes of perception of oneself correlated with the use of instrumental support, self-distraction, and venting. Changes in relationships with others correlated with religion, use of emotional support, use of instrumental support, self-distraction, denial, and venting. Greater appreciation for life correlated with self-distraction, denial, and venting. Finally, spiritual changes correlated with religion, use of instrumental support, venting, and behavioral disengagement.

There were some differences between the genders. Here, we focused on correlations that did not show up as significant for the whole group but were significant for one or the other gender. Hence, in the case of global PTG, men did not show any significant correlations. When analyzing correlations of Brief COPE to dimensions of PTG, for men changes in relationships 
TABLE 5 | Stepwise linear regression analysis for all participants.

\begin{tabular}{|c|c|c|c|c|}
\hline & B & SE & $\beta$ & $t$ \\
\hline \multicolumn{5}{|c|}{ Global posttraumatic growth } \\
\hline Partnership status & -9.267 & 4.331 & $-0.215^{\star}$ & -2.140 \\
\hline Education & -12.659 & 4.086 & $-0.312^{\star \star}$ & -3.098 \\
\hline \multicolumn{5}{|c|}{ Changes in perception of oneself } \\
\hline $\mathrm{Cl}$ experience (years) & 0.441 & 0.130 & $0.317^{\star \star}$ & 3.398 \\
\hline \multicolumn{5}{|c|}{ Changes in relationship with others } \\
\hline Education & -2.872 & 1.081 & $-0.251^{\star \star}$ & -2.656 \\
\hline \multicolumn{5}{|c|}{ Greater appreciation for life } \\
\hline Gender & 1.468 & 0.699 & $0.190^{\star}$ & 2.102 \\
\hline $\mathrm{Cl}$ experience (years) & 0.183 & 0.067 & $0.248^{\star \star}$ & 2.740 \\
\hline \multicolumn{5}{|l|}{ Spiritual changes } \\
\hline Gender & 1.703 & 0.558 & $0.269^{\star \star}$ & 3.052 \\
\hline Education & -2.682 & 0.573 & $-0.413^{\star \star \star}$ & -4.681 \\
\hline
\end{tabular}

Gender, sociodemographics, $\mathrm{Cl}$ and hearing status as predictors of posttraumatic growth (PTGl). Only significant variables are shown. ${ }^{\star} P<0.05 ;{ }^{\star \star} P<0.01 ;{ }^{\star \star \star} P<0.001$.

with others correlated with the use of instrumental support, and spiritual changes correlated with coping using religion. For women, in the case of global PTG there were significant correlations with active coping, planning, and use of emotional support. For dimensions of PTG, women showed significant correlations between changes in perception of oneself and active coping and with planning. For changes in relationships with others, there were significant correlations with acceptance and use of emotional support. For spiritual changes, there were significant correlations with religion and denial.

\section{Regression Analysis}

Regression analysis was performed for PTGI and all personal characteristics and variables related to deafness and CI-age at CI, deafness experience, CI experience, and CI satisfaction-and the results are shown in Table 5. In the case of global PTG, the predictors were partnership status and education. People who were in a relationship had higher global PTG. On the contrary, people with lower education had higher global PTG.

The only significant predictor of changes in perception of oneself was CI experience-the longer the better. The only significant predictor of changes in relationship with others was education-again the lower the better. The predictors of greater appreciation for life were gender (better for women) and also CI experience (the longer the better). Predictors of spiritual changes were gender (better for women) and also education (again the lower the better).

Finally, regression analysis was performed, for global PTG and the four PTG dimensions, using coping strategies (Brief COPE results) as predictors (Table 6). For all participants, there were two strong predictors of global PTG, namely, the use of instrumental support and denial. However, for men there was only one predictor, i.e., denial, whereas for women there were three predictors, i.e., active coping, use of emotional support, and denial.
When coping strategies (Brief COPE) were used as predictors of changes of perception of oneself, the main predictor for the group as a whole was self-distraction. However, for men it was denial, whereas in the female subgroup there were also planning and self-distraction. For the whole group the predictors of changes in relationships with others were use of instrumental support and denial. For men, the predictors were active coping and instrumental support, whereas for women there were in addition acceptance, denial, and self-blame. As predictors of greater appreciation for life, Brief COPE revealed self-distraction for the whole group and, for men, planning as well; however, for women, there were no significant predictors at all. Finally, when looking for predictors of spiritual changes, the significant coping strategies were planning, religion, and use of instrumental support. Planning and religion were significant predictors among men, whereas religion and instrumental support were significant predictors among women.

\section{DISCUSSION}

This study has attempted to measure the occurrence of PTG in individuals who have experienced profound (or total) postlingually acquired hearing loss and are currently using a CI. We also investigated the links between PTG level and sociodemographic characteristics, as well as variables related to deafness and CI, but above all with coping strategies. To the best of our knowledge, these are the first studies on the occurrence of PTG, and its relation to coping strategies in CI users (looking also at the role of gender).

\section{Posttraumatic Growth in Postlingually Deaf CI Users}

The results indicate that, like other trauma sufferers, postlingually deaf CI users undergo PTG and reach a similar level to those who have had spinal cord injury (Byra, 2016), AIDS/HIV 
TABLE 6 | Stepwise linear regression analysis for all participants and according to gender.

\begin{tabular}{l|lll}
\multicolumn{3}{c}{ All participants } \\
\hline B & SE & $\beta$ & $t$
\end{tabular}

\section{Global posttraumatic growth}

Use of instrumental support

$\begin{array}{rrrr}10.185 & 3.469 & 0.293^{\star \star} & 2.936 \\ 7.904 & 2.415 & 0.326^{\star \star} & 3.272 \\ & & & 3.682 \\ 4.452 & 1.209 & 0.357^{\star \star \star} & 3.748 \\ & & & 2.870 \\ 4.052 & 1.081 & 0.368^{\star \star \star} & 3.699 \\ 2.114 & 0.737 & 0.282^{\star \star} & \\ & & & -2.255 \\ 1.443 & 0.390 & 0.340^{\star \star \star} & 8.500 \\ -0.809 & & & 2.632 \\ 1.842 & 0.359 & -0.164^{\star} & 0.633^{\star \star \star} \\ 1.013 & 0.217 & 0.197^{\star} & \end{array}$

Denial

Changes in perception of oneself

Self-distraction

Changes in relationship with others

Use of instrumental support

Denial

\section{for life}

Greater appreciation for life

Self-distraction

Spiritual changes

Planning

Religion

Use of instrumental support

\section{Men}

$\begin{array}{llll}\text { B } & \text { SE } & \beta & t\end{array}$

\section{Global posttraumatic growth}

Denial

\section{Changes in perception of oneself}

Denial

Changes in relationship with others

Active coping

\subsection{6}

7.241

$-3.537$

6.456

Use of instrumental support

Greater appreciation for life

Planning

Self-distraction

$-1.428$

2.040

$-1.564$

Planning

Religion

5.030

2.865

1.267

1.516

0.629

0.589

0.456

0.349

\section{$0.354^{*}$}

$0.371^{*}$

$-0.378^{\text {** }}$

$0.576^{\star \star \star}$

$-0.294^{*}$

$0.449^{\star \star}$

$-0.390^{\star *}$

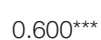

2.299

2.528

$-2.792$

4.260

$-2.269$

3.463

$-3.427$ 5.280

Women

\begin{tabular}{l|ll} 
B & SE & $\beta$
\end{tabular}

Global posttraumatic growth

Active coping

20.841

3.857

3.062

8.146

8.397

2.322

$0.568^{\star \star \star}$

5.404

Use of emotional support

7.894

5.954

2.190

$0.278^{*}$

$0.378^{\star *}$

2.660

\section{Changes in perception of oneself}

\section{Planning}

5.954

\section{Changes in relationship with others}

Active coping

$$
2.414
$$

2.898

Use of instrumental support

Denial

Self-blame

3.115

1.606

$-1.973$

Spiritual changes

Religion

Use of instrumental support

\subsection{9}

1.493
1.654

1.074

1.044

1.011

0.699

0.884

0.278

0.510 $0.409^{\text {** }}$

$0.409^{\text {** }}$

$0.253^{*}$

$0.300^{\text {** }}$

$0.332^{\text {** }}$

$0.255^{*}$

$-0.253^{\text {** }}$

$0.647^{\star \star \star}$

$0.285^{\text {** }}$
3.615

3.605

3.599

2.247

2.777

3.079

2.296

$-2.233$

6.640

2.929

Coping strategies (Brief COPE) as predictors of posttraumatic growth (PTGI). Only significant variables are shown.

${ }^{\star} P<0.05 ;{ }^{* *} P<0.01 ;{ }^{* \star *} P<0.001$. 
diagnosis (Rzeszutek et al., 2016; Rzeszutek and Gruszczyńska, 2018), breast cancer (Cordova et al., 2001; Koutrouli et al., 2014; Andysz et al., 2015), or serious heart disease (Bluvstein et al., 2013). Referring to Polish sten norms for trauma sufferers (Juczyński and Ogińska-Bulik, 2010), it can be said that $31 \%$ of postlingually deaf CI users experienced a high level of PTG and $32 \%$ experienced a medium level. In total, this means we should expect that about two-thirds of our study participants went through PTG following their postlingual profound hearing loss or deafness.

\section{PTG and Sociodemographic Characteristics}

From a meta-analysis of research into PTG, it appears that the female gender is associated with a higher PTG in response to stressful events (Barskova and Oesterreich, 2009; Vishnevsky et al., 2010; Ogińska-Bulik, 2015; Akbar and Witruk, 2016; Rzeszutek and Gruszczyńska, 2018; Wu et al., 2019). In our study, female gender proved to be a significant predictor in two dimensions of PTG, namely, the spiritual changes domain and greater appreciation for life. Other research also indicates the important role of gender in experiencing PTG in the area of spiritual changes (Steel et al., 2008; Cormio et al., 2015; Rzeszutek et al., 2016).

It turned out, however, that lower education was a good predictor of PTG-not just for global PTG but also for positive changes in the spiritual domain and in relationships with others. Similar results between PTG and lower education have been obtained by a few other researchers in relation to women with breast cancer (Cordova et al., 2001; Koutrouli et al., 2014), in long-term colorectal cancer survivors (Jansen et al., 2011), in persons after bone marrow transplantation for cancer (Widows et al., 2005), in patients with coronary artery disease (Leung et al., 2012), and in patients in the years after lung transplantation (Fox et al., 2014), as well as in women after induced abortion (Barraza Illanes and Calvo-Francés, 2018).

Our research shows that lower education contributes to the development of PTG. Perhaps, as other researchers have pointed out, people with lower education (and thus of generally lower socio-economic status) experience more hardship in their lives and so have more experience in finding the positive side of highly stressful life events (Ross and Van Willigen, 1997; Jansen et al., 2011). It is also possible that less educated people have lower expectations in various spheres of life, including in relation to other people, which may be associated with feeling less dissatisfied than do more educated persons (Ross and Van Willigen, 1997), and in consequence they experience higher PTG. However, the direction of the relationship between PTG and the level of education requires further research.

Among the sociodemographic variables, marital or partnership status proved to be very important, and hence the relationship between the spouse and the partner seems to favor the development of PTG. This points to the interpersonal aspect of PTG: the creators of the PTG concept, Tedeschi and Calhoun, themselves indicate the importance of relations with people and of social support (Calhoun and Tedeschi, 2014), findings similar to those of other PTG studies (Barskova and Oesterreich, 2009; Harding et al., 2014; Ogińska-Bulik, 2015; Rzeszutek and Gruszczyńska, 2018; Sörensen et al., 2019). Other sociodemographic characteristics such as age or employment status did not show a link with PTG.

\section{PTG and Deafness-Related Factors}

The duration of deafness correlated with positive changes after the trauma, especially in the dimensions of changes in perception of oneself and changes in relationships with others, although this relationship applied only to men. The creators of the PTG concept, Tedeschi and Calhoun, believed that the time elapsed from trauma is conducive to experiencing positive changes (Calhoun and Tedeschi, 2014), but the results of research on the relationship between the elapsed time and PTG are inconclusive (Barskova and Oesterreich, 2009; Koutrouli et al., 2014; OgińskaBulik, 2015; Rzeszutek and Gruszczyńska, 2018). Some others pointed to similar positive relationships, as found in the case of long-term disease-free cancer survivors (Cormio et al., 2015), women with breast cancer (Cordova et al., 2001), or mothers of deaf children experiencing PTG associated with the diagnosis of deafness in their child (Kobosko, 2016). However, it should be noted that in the few studies reporting PTG, there was always a long period of coping with CID, as was the case in our study.

The duration of CI experience turned out to be a predictor of PTG in postlingually deaf CI users in relation to two PTG dimensions, namely, changes in perception of oneself and greater appreciation of life. This result indirectly shows that a CI is highly important to users, a conclusion often supported by the CI users themselves, who, especially in qualitative research, report the enormous benefits associated with a CI not only in the hearingrelated sphere but also in many spheres of life (Hallberg and Ringdahl, 2004; Heydebrand et al., 2005; Kennedy et al., 2008; Rembar et al., 2009; Ramos-Macías et al., 2016). In our research, we considered the CI to be an object that the person has sought out in response to their hearing loss (i.e., the CI is a part of the coping strategy of users-specifically, it is active coping or coping by instrumental support). A similar positive relationship has been found between the time since a heart transplant and PTG (Juczyński and Ogrodnik, 2017). However, it should be remembered that recovery from some illnesses can be enhanced by PTG and well-being (Calhoun and Tedeschi, 2014; OgińskaBulik, 2015; Martz and Livneh, 2016), suggesting that people experiencing PTG are more able to appreciate what cochlear implantation offers them and the "return to the world of sounds." In future, more longitudinal studies are needed to explore the relationship between PTG and the time since trauma of hearing loss or the time since medical intervention, such as receiving a CI, took place (Wu et al., 2019). Other variables related to deafnessthe age at which the CI was received and satisfaction with the device-did not show links with the development of PTG.

\section{Coping With Stress in Postlingually Deaf $\mathbf{C l}$ Users in Relation to Gender}

It turned out that postlingually deaf women with a CI, more often than did deaf men with CI, resorted to avoidance-oriented coping strategies when confronted with stress, including self-distraction, 
denial, and venting, which, in the long run, are mostly regarded as ineffective (Roth and Cohen, 1986; Ottenbreit and Dobson, 2008; Ogińska-Bulik, 2015; Wu et al., 2019). This result may point to higher mental health problems in postlingually deaf women because we know that, for example, in response to stress, there is a connection between avoidance-oriented coping and depressive symptoms (Ottenbreit and Dobson, 2008). The results of other studies indicate that postlingually deaf women, as compared with postlingually deaf men, exhibit a higher level of mental distress, including depression or anxiety (de Graaf and Bijl, 2002; Kvam et al., 2007; Fellinger et al., 2012; Kim et al., 2017). In our study, deaf women with a CI also used strategies related to seeking emotional and instrumental support more often than did men, as well as turning to religion (favoring PTG), which is also indicated by the results we obtained.

\section{PTG and Coping With Stress in Postlingually Deaf $\mathrm{CI}$ Users}

The results show that, in postlingually deaf people with CIs, both approach-oriented and avoidance-oriented coping strategies are significantly associated with PTG. In effecting positive changes after the trauma of hearing loss, an important coping strategy in our study group was turning to religion and seeking social support, both of which can be categorized as employing emotional or instrumental support.

\section{PTG and Approach- and Avoidance-Oriented Coping Strategies}

Among the several approach-oriented coping strategies that foster global PTG, two were active coping and planning, and these strategies were found to have positive predictive power, but only for women. Here, a positive relationship with PTG occurred in the dimensions of self-perception and in global PTG. Only in women did this acceptance-coping strategy play an important role in developing positive changes in relations with other people. In other studies, such as in those with spinal cord injury or cancer patients, effective strategies_-such as taking additional action or trying to get rid of the problem-have been strongly associated with PTG (Barskova and Oesterreich, 2009; Scrignaro et al., 2011; Ogińska-Bulik, 2015; Wu et al., 2019). In cases of people with CID, acceptance helps facilitate PTG, as has been found in studies with cancer patients (Prati and Pietrantoni, 2009), liver transplant recipients (Pérez-San-Gregorio et al., 2017), and rheumatoid arthritis patients (Rzeszutek et al., 2017).

In contrast, for postlingually deaf men with CIs, an active coping strategy was not conducive to PTG, especially in the area of relations with other people, where it remained a negative correlation. The coping strategy of planning also played an important role in two areas of PTG in men with postlingual deafness, but as in the case with the active coping strategy, the use of this strategy was associated with a lower level of PTG. This probably happens because activity (i.e., active coping and planning) does not focus on solving the problem; instead, the men were trying to cope emotionally with the situation, and having to deal with negative emotions while adapting to their chronic disability (Livneh, 2009; Kelly et al., 2018).
As far as strategies related to avoidance-oriented coping are concerned, denial remained in a positive relation to global PTG for the whole group of study participants, both men and women, being a predictor in the areas of PTG change in relations with others (women) and changes in perception of oneself (men). Denial, i.e., "I reject the idea this ever happened," is already known to be a coping strategy that does not generally lead to good health (Livneh, 2009), positive treatment outcomes (e.g., satisfaction with their CI; Kobosko et al., 2015), or successful adaptation to the acquired disability (Livneh, 2009). Nevertheless, recent studies indicate that the use of this strategy can promote PTG, and hence play a positive role in psychological adaptation to CID. For example, PTG emanating from denial has been seen in liver transplant recipients (Pérez-San-Gregorio et al., 2017), people with spinal cord injury (Kunz et al., 2018), stroke survivors (Kelly et al., 2018), and earthquake survivors (Akbar and Witruk, 2016). However, the positive or negative effect of denial will vary, depending (among other things) on the stage of adaptation to the highly stressful life event, the time since it occurred, and its context.

Kunz et al. (2018) suggested an explanation that points to the flexible use of different types of coping strategies, i.e., use of both approach- and avoidance-oriented strategies (coping flexibility) facilitates PTG, and this will of course be available to people with postlingual deafness. It might also be presumed that the use of denial serves to reduce distress, and hence facilitates PTG, as other researchers have suggested (Kelly et al., 2018). It should be acknowledged, however, that in the case of some postlingually deaf subjects with a CI, the PTG may be illusory, as in the Janus-face model of PTG (Zoellner and Maercker, 2006). This question still requires further research, perhaps by using clinical psychological diagnosis of survivors of trauma, including hearing loss.

Self-distraction (i.e., avoiding thinking about the consequences of a stressful life event by engaging in other activities such as sleep, binge eating, or watching TV) is another coping strategy classed as avoidance-oriented. We found that it actually favors PTG in postlingually deaf people with a CI and was a predictor of PTG change in the perception of oneself (in women), and in the sphere of greater appreciation of life (in men). Its role in the development of PTG is similar to that of others in this group, i.e., it favors reduction of mental distress (Akbar and Witruk, 2016; Kelly et al., 2018).

\section{PTG and Use of Social Support}

Social support is a psychosocial resource that, according to the model of Calhoun and Tedeschi (2014), promotes the development of PTG through activating cognitive processing of trauma, e.g., by finding the meaning of the traumatic event. The present results are consistent with other work on the subject, but point to a special role for the use of instrumental support. Although coping using this strategy worked for all study participants, it was stronger for women, where it turned out to be a predictor. For women, use of instrumental support was important for positive changes in relationships with others. Only for women who used this form of support did it predict positive PTG in the dimension of spiritual change. 
For postlingually deaf adults with a CI, it is particularly important to provide social support in the form of specific help, such as CI information and advice (included here in our definition of instrumental support coping). Help can take the form of support from a team of specialists-physician, speech therapist, psychologist, teacher, audiologist, or clinical engineerwho are called on when qualifying for a CI, during surgery, or later (during hearing and speech rehabilitation).

For all participants, the use of emotional support turned out to be a coping strategy well-correlated with changes in relationships with others, and, for women, with the development of global PTG and changes in relationships with others. This finding is consistent with the results of research on PTG in women with breast cancer (Barskova and Oesterreich, 2009; Koutrouli et al., 2014; Ogińska-Bulik, 2015). This result might be explained by a tendency for women to have more social contact and acceptance, particularly in Middle Eastern and European cultures, when reaching out for help and support (Akbar and Witruk, 2016; Sörensen et al., 2019). Familiar people, family, and friends, as well as other postlingually deaf CI patients in a similar situation, can be a source of enormous social, emotional, and instrumental support. This is especially true for significant others (i.e., partners), so, according to our results with postlingually deaf CI users, being in a relationship will support PTG.

\section{PTG and Turning to Religion}

Postlingually deaf people with a CI, especially women, more often reach for religion to cope than do people from the general population (Kobosko et al., 2012). In the cultures of Central and Eastern Europe, religion is a major source of support, especially during illness, cataclysm, and misfortune (Stecz and Kocur, 2015). For postlingually deaf participants with CIs, our results show that a religious coping strategy provides a positive, though weak, relationship with the development of global PTG; we found a correlation of PTG in the dimensions of change in relationships with others and with the domain of spiritual changes. As a predictor, religion turned out to be significant only for spiritual changes (in both women and men).

\section{Limitations and Ideas for Future Studies}

It would be interesting to conduct detailed longitudinal studies in this area, looking at PTG at various time intervals beginning from the incidence of hearing loss. The role of cochlear implantation in this process is still unexplored. In this study, we treated the $\mathrm{CI}$ as one manifestation of invoked coping strategies, in this way having an indirect effect on PTG. However, due to the widespread availability of CIs in many countries, it is currently difficult to find a control group of postlingually deaf people who do not use this hearing prosthesis.

In addition, since the responses of participants were anonymous, in this study it was not possible to correlate PTG results with objective benefits from using a CI. Subjective assessment of the CI, measured as CI satisfaction, was found not to be related to PTG. In further studies on PTG, it would be worth considering not only satisfaction with a CI but also prior expectations about receiving a $\mathrm{CI}$, and how these relate to its objective benefits. How PTG depends on these factors might help improve rehabilitation after receiving a CI, and also tell us more about the general psychosocial and hearing-related functioning of CI users.

It might also be helpful to collect the perspectives of family members and others close to the postlingually deaf person. In future studies, two groups of people with postlingual deafness and CIs might also be compared, i.e., those whose hearing deteriorated gradually and those who experienced sudden deafness.

Since we used a single PTGI questionnaire, this set of selfreported data could not be considered robust. Self-reported measures, in which "growth" changes are declared by the respondent, mean the answers might just reflect psychological defense mechanisms and that no real change actually occurred.

A particular limitation is the study group itself: it was heterogeneous due to the time that had elapsed since hearing loss. This factor is difficult to control when hearing loss occurs gradually; many of the subjects were then unable to say exactly how long ago they had lost their hearing. This time variable may be important, as cochlear implantation is just one of the actions/behaviors undertaken by postlingually deaf people to cope with their condition. Another limitation of the study is that the patient cohort was relatively small for thematic analysis, given the disparate nature of CI users.

This study used participants who agreed to fill in questionnaires, and in future it would be informative to use other approaches to gauging PTG, e.g., by using one-on-one clinical interviews. Although our study consistently found that coping strategies were related to PTG, the cross-cultural differences in this area cannot be ruled out.

\section{CONCLUSION}

In general, about two-third of postlingually deaf CI users in our study experienced PTG at a high or medium level. We found that the length of time since hearing was lost favors the development of PTG, especially in men. Also, the time elapsed since the CI operation-which we identify as the manifestation of an active coping strategy or of seeking instrumental support-turned out to work in favor of PTG.

We found in our study participants that a higher level of global PTG was associated with certain stress-coping strategies: for women mainly active coping, planning, use of emotional support, and denial; for men, denial, and, for all postlingually deaf CI users: use of instrumental support and denial. That is, both approach- and avoidance-oriented coping strategies are used in the development of global PTG.

An important issue is the availability of professional support. Practitioners need to be aware of PTG arising as a natural result of a highly stressful life event (but not in everybody)-severe and profound hearing loss in postlingually deaf CI users. This group of patients should be made aware of the positive role of PTG in adapting to their deafness, as well its role in improving hearing and speech rehabilitation. A parallel can be drawn to other clinical groups (say coronary disease outpatients) where it has been shown that there is a positive correlation between PTG 
and health service use-that is, greater PTG is connected with higher levels of rehabilitation program enrollment (Leung et al., 2012).

We believe that the various forms of psychological interventions and psychoeducation offered to postlingually deaf people with a CI should be targeted to those stress-coping strategies which favor PTG. However, it would be best to offer psychological interventions during the initial audiological rehabilitation-that is, psycho-education, psychotherapy, training in how to cope with the stress associated with acquired deafness, and self-help programs (Garnefski and Kraaij, 2012). As we now know, psychosocial adaptation to deafness and PTG are directly and positively related, and therefore are mutually beneficial.

\section{DATA AVAILABILITY STATEMENT}

The raw data supporting the conclusions of this article will be made available by the authors, without undue reservation, to any qualified researcher.

\section{REFERENCES}

Akbar, Z., and Witruk, E. (2016). Coping mediates the relationship between gender and posttraumatic growth. Proc. Soc. Behav. Sci. 217, 1036-1043. doi: 10.1016/j.sbspro.2016.02.102

Andysz, A., Najder, A., Merecz-Kot, D., and Wójcik, A. (2015). Posttraumatic growth in women after breast cancer surgery: preliminary results from a study of Polish patients. Health Psychol. Rep. 3, 336-344. doi: 10.5114/hpr.2015.52383

Baghjari, F., Esmaeilinasab, M., and Shahriari-Ahmadi, A. (2017). Predicting posttraumatic growth based on coping strategies in women and men involving with advanced cancer. Int. J. Cancer Manag. 10:e10193. doi: 10.5812/ijcm.10193

Barraza Illanes, P. A., and Calvo-Francés, F. (2018). Predictors of personal growth in induced abortion. Psicothema 30, 370-375. doi: 10.7334/psicothema2018.65

Barskova, T., and Oesterreich, R. (2009). Post-traumatic growth in people living with a serious medical condition and its relations to physical and mental health: a systematic review. Disabil. Rehabil. 31, 1709-1733. doi: 10.1080/09638280902738441

Benjamini, Y., and Hochberg, Y. (1995). Controlling the false discovery ratepractical and powerful approach to multiple testing. J. Royal Statist. Soc. Ser. B 57, 289-300. doi: 10.1111/j.2517-6161.1995.tb02031.x

Blamey, P., Artieres, F., Başkent, D., Bergeron, F., Beynon, A., Burke, E., et al. (2013). Factors affecting auditory performance of postlinguistically deaf adults using cochlear implants: an update with 2251 patients. Audiol. Neurootol. 18, 36-47. doi: 10.1159/000343189

Bluvstein, I., Moravchick, L., Sheps, D., Schreiber, S., and Bloch, M. (2013). Posttraumatic growth, posttraumatic stress symptoms and mental health among coronary heart disease survivors. J. Clin. Psychol. Med. Settings. 20, 164-172. doi: 10.1007/s10880-012-9318-z

Boals, A., Bedford, L. A., and Callahan, J. L. (2019). Perceptions of change after a trauma and perceived posttraumatic growth: a prospective examination. Behav. Sci. 9:e10. doi: 10.3390/bs9010010

Bostock, L., Sheikh, A. I., and Barton, S. (2009). Posttraumatic growth and optimism in health-related trauma: a systematic review. J. Clin. Psychol. Med. Settings 16, 281-296. doi: 10.1007/s10880-009-9175-6

Byra, S. (2016). Posttraumatic growth in people with traumatic long-term spinal cord injury: predictive role of basic hope and coping. Spinal Cord 54, 478-482. doi: $10.1038 /$ sc. 2015.177

Calhoun, L. G., and Tedeschi, R. G. (2014). "The foundations of posttraumatic growth: an expanded framework," in: Handbook of Posttraumatic Growth:

\section{ETHICS STATEMENT}

The studies involving human participants were reviewed and approved by the ethics committee of the Institute of Physiology and Pathology of Hearing, Warsaw, Poland. Written informed consent for participation was not required for this study in accordance with the national legislation and the institutional requirements.

\section{AUTHOR CONTRIBUTIONS}

JK: conceptualization. WJ: formal analysis. JK, WJ, DBP, AG-S, and HS: investigation. DBP and AG-S: resources. JK and WJ: data curation and writing-original draft preparation. AG-S and HS: supervision. HS: funding acquisition. All authors contributed to the article and approved the submitted version.

\section{ACKNOWLEDGMENTS}

The authors thank Andrew Bell for comments on earlier versions of this article.

Research and Practice, eds L. G. Calhoun and R. G. Tedeschi (New York, NY, London: Psychology Press Taylor \& Francis Group), 3-23.

Carver, C. S. (1997). You want to measure coping but your protocol's too long: consider the Brief COPE. Int. J. Behav. Med. 4, 92-100. doi: 10.1207/s15327558ijbm0401_6

Cordova, M. J., Cunningham, L. L. C., Carlson, C. M., and Andrykowski, M. A. (2001). Posttraumatic growth following breast cancer: a controlled comparison study. Health Psychol. 20, 176-185. doi: 10.1037/0278-6133.20.3.176

Cormio, C., Romito, F., Giotta, F., and Mattioli, V. (2015). Post-traumatic growth in the Italian experience of long-term disease-free cancer survivors. Stress Health 31, 189-196. doi: 10.1002/smi.2545

de Graaf, R., and Bijl, R. V. (2002). Determinants of mental distress in adults with a severe auditory impairment: differences between prelingual and postlingual deafness. Psychosom. Med. 64, 61-70 doi: 10.1097/00006842-200201000-00009

Du Feu, M. (2014). “Deafened people," in: Mental Health and Deafness, M. Du Feu and C. Chovaz (Oxford: Oxford University Press), 209-215.

Du Feu, M., and Fergusson, K. (2003). Sensory impairment and mental health. $A d v$. Psychiatr. Treat. 9, 95-103. doi: 10.1192/apt.9.2.95

Fellinger, J., Holzinger, D., and Pollard, R. (2012). Mental health of deaf people. Lancet 379, 1037-1044. doi: 10.1016/S0140-6736(11)61143-4

Fox, K. R., Posluszny, D. M., di Martini, A. F., deVito Dabbs, A. J., Rosenberger, E. M., Zomak, R. A., et al. (2014). Predictors of post-traumatic psychological growth in the late years after lung transplantation. Clin. Transplant. 28, 384-393. doi: 10.1111/ctr.12301

García, F. E., Páez, D., Reyes-Reyes, A., and Álvarez, R. (2017). Religious coping as moderator of psychological responses to stressful events: a longitudinal study. Religions 8:e62. doi: 10.3390/rel8040062

Garnefski, N., and Kraaij, V. (2012). Effects of a cognitive behavioral selfhelp program on emotional problems for people with acquired hearing loss: a randomized controlled trial. J. Deaf Stud. Deaf Educ. 17, 75-84. doi: 10.1093/deafed/enr020

Hallam, R., Ashton, P., Sherbourne, K., and Gailey, L. (2006). Acquired profound hearing loss: mental health and other characteristics of a large sample. Int. J. Audiol. 45, 715-723. doi: 10.1080/14992020600957335

Hallberg, L. R.-M., and Carlsson, S.G. (1993). A qualitative study of situations turning a hearing disability into a handicap. J. Disabil. Handicap Soc. 8, 71-86. doi: 10.1080/02674649366780051

Hallberg, L. R.-M., Hallberg, U., and Kramer, S. E. (2008). Self-reported hearing difficulties, communication strategies and psychological general well-being 
(quality of life) in patients with acquired hearing impairment. Disabil. Rehabil. 30, 203-212. doi: 10.1080/09638280701228073

Hallberg, L. R.-M., and Ringdahl, A. (2004). Living with cochlear implants: experiences of 17 adult patients in Sweden. Int. J. Audiol. 43, 115-121. doi: 10.1080/14992020400050016

Harding, S., Sanipour, F., and Moss, T. (2014). Existence of benefit finding and posttraumatic growth in people treated for head and neck cancer: a systematic review. Peer J. 2:e256. doi: 10.7717/peerj.256

Heydebrand, G., Mauze, E., Tye-Murray, N., Binzer, S., and Skinner, M. (2005). The efficacy of a structured group therapy intervention in improving communication and coping skills for adult cochlear implant recipients. Int. J. Audiol. 44, 272-280. doi: 10.1080/14992020500060404

Jansen, L., Hoffmeister, M., Chang-Claude, J., Brenner, H., and Arndt, V. (2011). Benefit finding and post-traumatic growth in long-term colorectal cancer survivors: prevalence, determinants, and associations with quality of life. $B r$. J. Cancer 105, 1158-1165. doi: 10.1038/bjc.2011.335

Juczyński, Z., and Ogińska-Bulik, N. (2009). "Inwentarz do pomiaru radzenia sobie ze stresem-mini COPE," in: Narzẹdzia Pomiaru Stresu i Radzenia Sobie ze Stresem, eds Z. Juczyński and N. Ogińska-Bulik (Warszawa: Pracownia Testów Psychologicznych PTP), 45-58.

Juczyński, Z., and Ogińska-Bulik, N. (2010). Rozwój potraumatycznycharakterystyka i pomiar [Posttraumatic growth: characteristics and measurement]. Psychiatria 7, 129-142.

Juczyński, Z., and Ogrodnik, I. (2017). Poczucie koherencji i spostrzegane wsparcie społeczne jako predyktory konsekwencji stresu po transplantacji serca. Psychiatria i Psychoterapia 13, 3-19.

Kashubeck-West, S., and Meyer, J. (2008). The well-being of women who are late deafened. J. Couns. Psychol. 55, 463-472. doi: 10.1037/a0013619

Kelly, G., Morris, R., and Shetty, H. (2018). Predictors of posttraumatic growth in stroke survivors. Disabil. Rehabil. 40, 2916-2924. doi: $10.1080 / 09638288.2017 .1363300$

Kennedy, V., Stephens, D., and Fitzmaurice, P. (2008). The impact of cochlear implants from the perspective of significant others of adult cochlear implant users. Otol. Neurotol. 29, 607-614. doi: 10.1097/MAO.0b013e318165652c

Kerr, P. C., and Cowie, R. I. D. (1997). Acquired deafness: a multi-dimensional experience. Br. J. Audiol. 31, 177-188. doi: 10.3109/03005364000000020

Kim, S. Y., Kim, H.-J., Park, E.-K., Joe, J., Sim, S., and Choi, H. G. (2017). Severe hearing impairment and risk of depression: a national cohort study. PLoS ONE. 12:e0179973. doi: 10.1371/journal.pone.0179973

Kobosko, J. (2015). Poczucie niepełnosprawności a percepcja siebie i objawy depresji u osób dorosłych z głuchota prelingwalna korzystajacych z implantu ślimakowego. Nowa Audiofonologia 4, 41-54. doi: 10.17431/894294

Kobosko, J. (2016). "Głuchota dziecka z perspektywy potraumatycznego wzrostu słyszạcych rodziców," in Jezyk i wychowanie. Ksiega jubileuszowa z okazji 45lecia pracy naukowej Profesor Kazimiery Krakowiak, eds E. Domagała-Zyśk, A. Borowicz and R. Kołodziejczyk (Lublin: Wydawnictwo KUL), 345-358.

Kobosko, J., Jedrzejczak, W. W., Pilka, E., Pankowska, A., and Skarzynski, H. (2015). Satisfaction with cochlear implants in postlingually deaf adults and its nonaudiological predictors: psychological distress, coping strategies, and self-esteem. Ear Hear. 36, 605-618. doi: 10.1097/AUD.00000000000 00179

Kobosko, J., Pankowska, A., and Skarzyński, H. (2012). Strategie radzenia sobie ze stresem u osób dorosłych postlingwalnie ogłuchłych korzystających z implantu ślimakowego, w porównaniu z populacjạ ogólnạ słyszạcych. Otolaryngol. Pol. 66, 132-137. doi: 10.1016/S0030-6657(12)70761-8

Koutrouli, N., Anagnostopoulos, F., and Potamianos, G. (2014). Posttraumatic stress disorder and posttraumatic growth in breast cancer patients: a systematic review. Women Health 52, 503-516. doi: 10.1080/03630242.2012. 679337

Kunz, S., Joseph, S., Geyh, S., and Peter, C. (2018). Coping and posttraumatic growth: a longitudinal comparison of two alternative views. Rehabil. Psychol. 63, 240-249. doi: 10.1037/rep0000205

Kvam, M. H., Loeb, M., and Tambs, K. (2007). Mental health in deaf adults: symptoms of anxiety and depression among hearing and deaf individuals. J. Deaf Stud. Deaf Educ. 12, 1-7. doi: 10.1093/deafed/enl015

Lassaleta, L., Castro, A., Bastarrica, M., de Sarriá, M. J., and Gavilán, J. (2006). Quality of life in postlingually deaf patients following cochlear implantation. Eur. Arch. Otorhinolaryngol. 263, 267-270. doi: 10.1007/s00405-005-0987-1
Lazard, D. S., Vincent, C., Venail, F., Van de Heyning, P., Truy, E., Sterkers, O., et al. (2012). Pre-, per- and postoperative factors affecting performance of postlinguistically deaf adults using cochlear implants: a new conceptual model over time. PLoS ONE 7:e48739. doi: 10.1371/journal.pone.0048739

Leung, Y. W., Alter, D. A., Prior, P. L., Stewart, D. E., Irvine, J., and Grace, S. L. (2012). Posttraumatic growth in coronary artery disease outpatients: relationship to degree of trauma and health service use. J. Psychosom. Res. 72, 293-299. doi: 10.1016/j.jpsychores.2011.12.011

Livneh, H. (2009). Denial to chronic illness and disability: Part I. Theoretical, functional, and dynamic perspectives. Rehabil. Couns. Bull. 52, 225-236. doi: $10.1177 / 0034355209333689$

Łosiak, W., and Nikiel, J. (2014). Posttraumatic growth in patients after myocardial infarction: the role of cognitive coping and experience of life threat. Health Psychol. Report 2, 256-262. doi: 10.5114/hpr.2014.45894

Manchaiah, V., Baguley, D. M., Pyykkö, I., Kentala, E., and Levo, H. (2015). Positive experiences associated with acquired hearing loss, Ménière's disease, and tinnitus--a review. Int. J. Audiol. 54, 1-10. doi: 10.3109/14992027.2014.953217

Martz, E., and Livneh, H. (2016). Psychosocial adaptation to disability within the context of positive psychology: findings from the literature. J. Occup. Rehabil. 26, 4-12. doi: 10.1007/s10926-015-9598-x

Mazurkiewicz, A., Otrębski, W., and Makara-Studzińska, M. (2015). Posttraumatic growth in case of women treated with irradiation due to cancer. Onkologia $i$ Radioterapia 1, 31-40.

Ogińska-Bulik, N. (2013). Potraumatyczny wzrost--zróżnicowanie ze względu na rodzaj doświadczonego zdarzenia oraz płeć i wiek badanych osób. Acta Universitatis Lodziensis Folia Psychologica 17, 51-66.

Ogińska-Bulik, N. (2014). Rola strategii radzenia sobie ze stresem w rozwoju po traumie u ratowników medycznych. Med. Pr. 65, 209-217.

Ogińska-Bulik, N. (2015). Dwa oblicza traumy. Negatywne i pozytywne skutki zdarzeń traumatycznych u pracowników sluzb ratowniczych. Warszawa: Difin.

Ottenbreit, N. D., and Dobson, K. S. (2008). "Avoidance," in Risk Factors in Depression, eds K. S. Dobson and D. J. A. Dozois (San Diego, CA: Elsevier Academic Press), 447-470. doi: 10.1016/B978-0-08-045078-0.00020-4

Pérez-San-Gregorio, M. Á., Martín-Rodríguez, A., Borda-Mas, M., AvarguesNavarro, M. L., Pérez-Bernal, J., and Gómez-Bravo, M. Á. (2017). Coping strategies in liver transplant recipients and caregivers according to patient posttraumatic growth. Front. Psychol. 8:e18. doi: 10.3389/fpsyg.2017.00018

Prati, G., and Pietrantoni, L. (2009). Optimism, social support and coping strategies contributing to posttraumatic growth: a meta-analysis. J. Loss Trauma 14, 364-388. doi: 10.1080/15325020902724271

Rajandram, R. K., Jenewein, J., McGrath, C., and Zwahlen, R. A. (2011). Coping processes relevant to posttraumatic growth: an evidence-based review. Support. Care Cancer 19, 583-589. doi: 10.1007/s00520-011-1105-0

Ramos-Macías, Á., Falcón González, J. C., Borkoski-Barreiro, S. A., Ramos de Miguel, Á., Batista, D. S., and Pérez Plasencia, D. (2016). Health-related quality of life in adult cochlear implant users: a descriptive observational study. Audiol. Neurotol. 21(Suppl.1), 36-42. doi: 10.1159/000448353

Rembar, S., Lind, O., Arnesen, H., and Helvik, A. S. (2009). Effects of cochlear implants: a qualitative study. Cochlear Implants Int. 10, 179-197. doi: 10.1179/cim.2009.10.4.179

Ross, C. E., and Van Willigen, M. J. (1997). Education and the subjective quality of life. Health Soc. Behav. 38, 275-297. doi: 10.2307/2955371

Rostkowska, J., Wojewódzka, D., Kobosko, J., Geremek-Samsonowicz, A., and Skarżyński, H. (2012). Możliwości słuchowe dorosłych osób ogłuchłych zaopatrzonych w implant ślimakowy. Nowa Audiofonologia 1, 46-49. doi: $10.17431 / 882781$

Roth, S., and Cohen, L. J. (1986). Approach, avoidance, and coping with stress. Am. Psychol. 41, 813-819. doi: 10.1037/0003-066X.41.7.813

Rzeszutek, M., and Gruszczyńska, E. (2018). Posttraumatic growth among people living with HIV: a systematic review. J. Psychosom. Res.114, 81-91. doi: 10.1016/j.jpsychores.2018.09.006

Rzeszutek, M., Oniszczenko, W., and Firlag-Burkacka, E. (2016). Gender differences in posttraumatic stress symptoms and the level of posttraumatic growth among a Polish sample of HIV-positive individuals. AIDS Care 28, 1411-1415. doi: 10.1080/09540121.2016.1182615

Rzeszutek, M., Oniszczenko, W., and Kwiatkowska, B. (2017). Stress coping strategies, spirituality, social support and posttraumatic growth in a Polish 
sample of rheumatoid arthritis patients. Psychol. Health Med. 22, 1082-1088. doi: 10.1080/13548506.2017.1280174

Scrignaro, M., Barni, S., and Magrin, M. E. (2011). The combined contribution of social support and coping strategies in predicting post-traumatic growth: a longitudinal study on cancer patients. Psychooncology 20, 823-831. doi: $10.1002 /$ pon. 1782

Skarżyński, H., Janczewski, G., Niemczyk, K., Kochanek, K., Geremek, A., and Klasek, O. (1993). Pierwszy implant ślimakowy w Polsce. Otolaryngol. Pol. $47,427-434$.

Sörensen, J., Rzeszutek, M., and Gasik, R. (2019). Social support and post-traumatic growth among a sample of arthritis patients: analysis in light of conservation of resources theory. Current Psychol. 2019, 1-9. doi: 10.1007/s12144-019-0131-9

Stecz, P., and Kocur, J. (2015). Religiousness, religious coping with illness, and psychological function among Polish elderly patients with osteoarthritis undergoing arthroplasty. J. Relig. Health 54, 554-570. doi: 10.1007/s10943-014-9842-2

Steel, J. L., Gamblin, T. C., and Carr, B. I. (2008). Measuring post-traumatic growth in people diagnosed with hepatobiliary cancer: directions for future research. Oncol. Nurs. Forum 35, 643-650. doi: 10.1188/08.ONF.643-650

Stephens, D., and Kerr, P. C. (2003). The role of positive experiences in living with acquired hearing loss. Int. J. Audiol. 42(Suppl.1), S118-S127. doi: $10.3109 / 14992020309074633$

Tedeschi, R. G., and Calhoun, L. G. (1996). The Posttraumatic Growth Inventory: measuring the positive legacy of trauma. J. Trauma. Stress 9, 455-471. doi: $10.1002 /$ jts. 2490090305

Tedeschi, R. G., and Calhoun, L. G. (2004). Posttraumatic growth: conceptual foundations and empirical evidence. Psychol. Inq. 15, 1-18. doi: 10.1207/s15327965pli1501_01

Vishnevsky, T., Cann, A., Calhoun, L. G., Tedeschi, R. G., and Demakis, G. J. (2010). Gender differences in self-reported posttraumatic growth: a meta-analysis. Psychol. Women Q. 34, 110-120. doi: $10.1111 / j .1471-6402.2009 .01546 . x$
Widows, M. R., Jacobsen, P. B., Booth-Jones, M., and Fields, K. K. (2005), Predictors of posttraumatic growth following bone marrow transplantation for cancer. Health Psychol. 24, 266-273. doi: 10.1037/0278-6133.24.3. 266

Williams, K. C., Falkum, E., and Martinsen, E. W. (2015). Fear of negative evaluation, avoidance and mental distress among hearing-impaired employees. Rehabil. Psychol. 60, 51-58. doi: 10.1037/rep0000028

Wu, X., Kaminga, A. C., Dai, W., Deng, J., Wang, Z., Pan, X., et al. (2019). The prevalence of moderate-to-high posttraumatic growth: a systematic review and meta-analysis. J. Affect. Disord. 243, 408-415. doi: 10.1016/j.jad.2018.09. 023

Zoellner, T., and Maercker, A. (2006). Posttraumatic growth in clinical psychology-a critical review and introduction to a two component model. Clin. Psychol. Rev. 26, 626-653. doi: 10.1016/j.cpr.2006.01.008

Conflict of Interest: The authors declare that the research was conducted in the absence of any commercial or financial relationships that could be construed as a potential conflict of interest.

Publisher's Note: All claims expressed in this article are solely those of the authors and do not necessarily represent those of their affiliated organizations, or those of the publisher, the editors and the reviewers. Any product that may be evaluated in this article, or claim that may be made by its manufacturer, is not guaranteed or endorsed by the publisher.

Copyright $\odot 2021$ Kobosko, Jedrzejczak, Porembska, Geremek-Samsonowicz and Skarzynski. This is an open-access article distributed under the terms of the Creative Commons Attribution License (CC BY). The use, distribution or reproduction in other forums is permitted, provided the original author(s) and the copyright owner(s) are credited and that the original publication in this journal is cited, in accordance with accepted academic practice. No use, distribution or reproduction is permitted which does not comply with these terms. 